\title{
Investigating the Philosophical Origin of Community Education in the Citizen Participation Process from the Perspective of Islamic Realism
}

\author{
Nastaran Najdaghi* \\ PhD in Islamic Urbanism, Head of Urban Regeneration Bureau,Municipality of Shiraz, Shiraz, Iran. \\ (Received 7 Oct 2020, Accepted 16 Jan 2021)
}

During the evolution of the urban development approach, attention to social participation has led to formation of community-led urban management. Social participation can improve social capital, sense of place, through community-led urban development process. Based on the views of the theorists, social participation can also create social sustainability. Since the sufficient skills and knowledge are needed to take part in decision-making process with the aim of social participation in local development projects, it seems that the lack of training required was due to failure in social participation. The educating will be assumed as the means to achieve enabling, empowering, capacity building and institutionalization for residents. Disregarding the role of residents who live in urban neighborhoods is the most important reason of failure to implement urban development in Iran. It is the result of lack of planning to attract participation not their teaching, not to teach people with the aim transferring experiences and to make appropriate methods to paradigm shift in the participants. On the other hand, there are not enough awareness and expertise in the urban management groups. In addition, it is necessary to produce conceptual frameworks for educating, training and teaching residents based on creed, native culture and identity of Islamic-Iranian society. This study focuses on specifying the position of social education and training during common participation attraction process and also clarifying the theoretical and philosophical basis of Islamic Ideology about social education with emphasis on the role of community and participation concept. Likewise, in order to Islamic thought's disciplines about social education and training and social behaviors in the community, defining the aims, principles, methods and contents of social education and training affecting Islamic thought organize the main purposes of this study. The method of this research as its purpose is decisive and based on its social science nature is descriptive. With the purpose to define attribute of social education and training affected Islamic theology, two viewpoints are compared: Islamic Realistic philosophy and its Etebariat theory versus some theories about participation in urbanism and urban planning which have been based on social education and training. Finally, the results of study represent that based on Islamic realistic philosophy, the paradigm is educating and training from society and for society are the main purpose. The conclusion shows that educating to society has no expected results. The values of this society have been specified based on anthropology. There are hierarchical aims based on Islamic philosophy and in accordance with these goals, the characteristics of education to the community have been explained. In general, despite the differences in the titles used to explain the theoretical and philosophical foundations of each of the two views there are similarities in the general orientation of explaining the role of education and training to the community to strengthen social responsibility and participation in both perspectives. As a conclusion, it should be said that conscious participation requires education, which should be explained in the context of the Islamic worldview and the principles of education in Islam.

Keywords: Education, Society, Islamic Realism, Participation, Urbanism.

\footnotetext{
*Corresponding author. E-mail: najdaghi@ut.ac.i 
واكاوى خاستًَاه فلسفى آموزش به اجتماع در فرايند مشار كت يذيرى شمروندان از منظر روش رئاليسم اسلامى أموسى

\author{
نسترن نزوداغى"

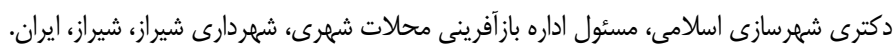

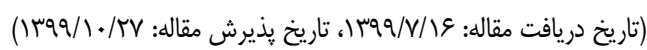

جكيده

مشاركت امرى مهم در برنامهريزى شهرى است؛ يكىاز عوامل ناموفق بودن اجراى بروزههاى توسعه محلات شهرى در ايران عدم توجه به نقش ساكنان است. اين مهم، حاصل فقدان برنامهريزى لازم براى جلب مشـاركت حسداكثرى

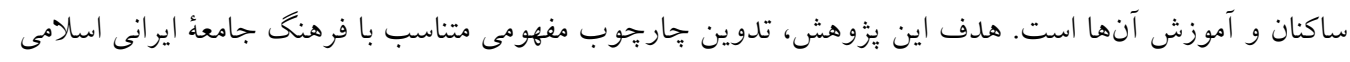

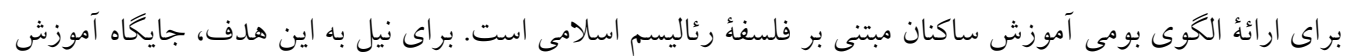
در فرايند جلب مشاركت مردمى مبتنى بر مبانى فلسفى انديشهُ اسلامى درباب آموزش، با توجه بـهـ نقـش اجتمـاع و

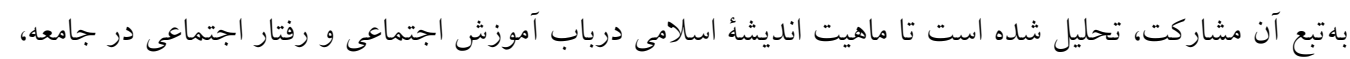

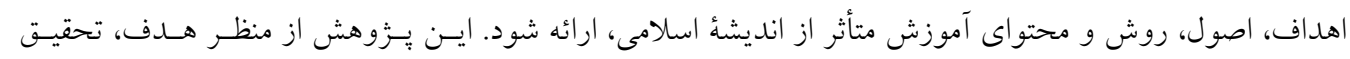

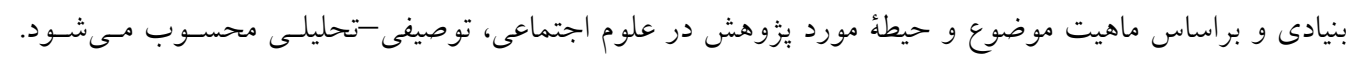

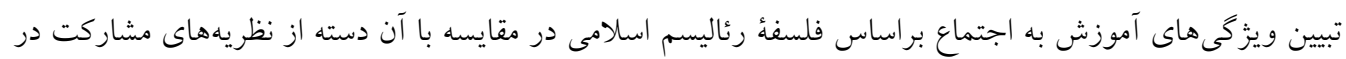

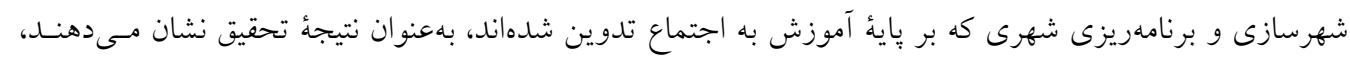

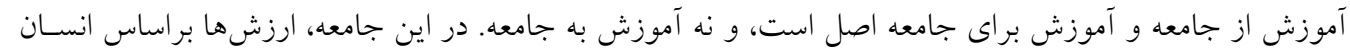

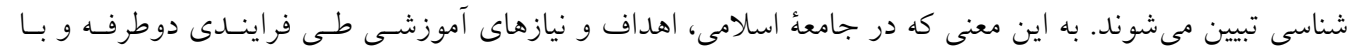

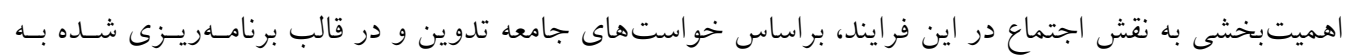
جامعه ارائه مى شوند.

$$
\text { وازگًان كليدى }
$$

آموزش، اجتماع، رئاليسم اسلامى، مشـاركت. 


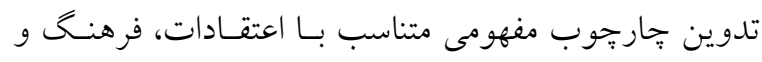

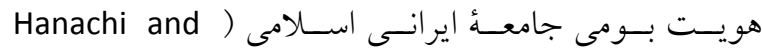
(Fadaienejad 2011

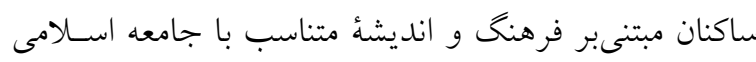

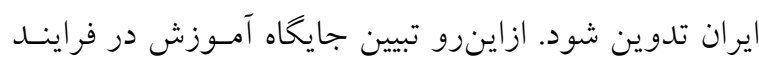

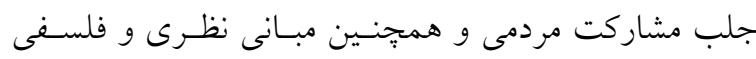

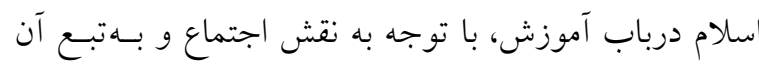

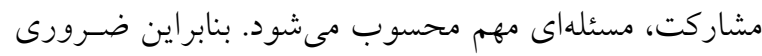

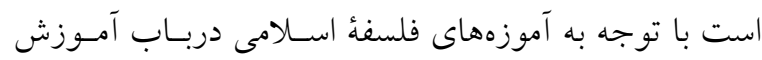

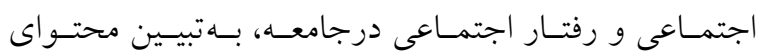

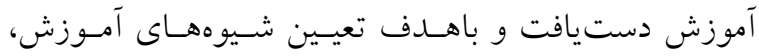
باستعانت از ديدكاههـاى نـوين، متــأثراز ديــــاه (اوضـعيت

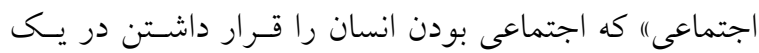

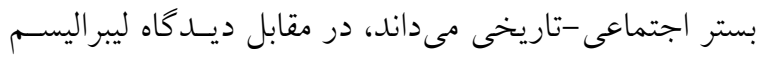

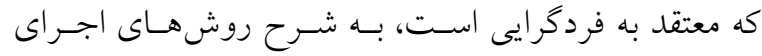

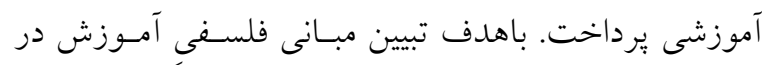

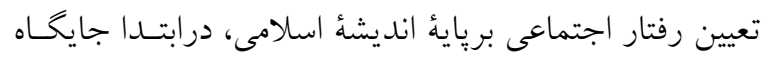

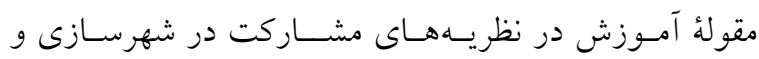

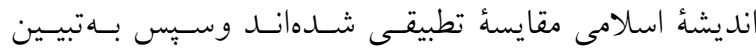

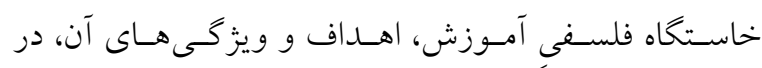
رئاليسم|سلامى برداختهشدهاست.

درتبيين مفاهيم مرتبط با رفتار اجتماعى انسانها مـلاكى عمل

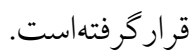

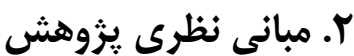

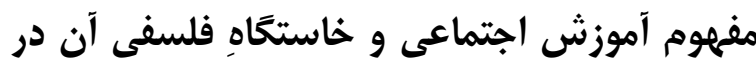

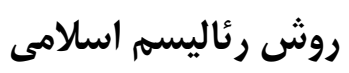

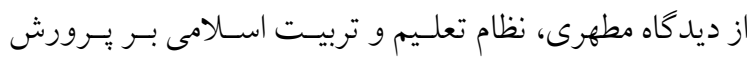

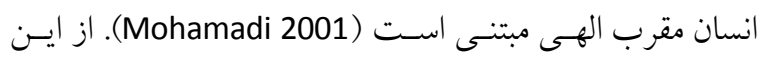

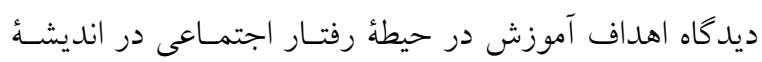

در فرايند توسعلُ محلات شهرى در ايران، علىرغــم وجـود

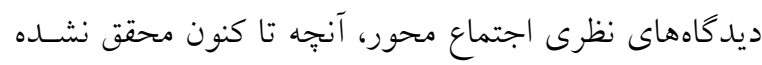

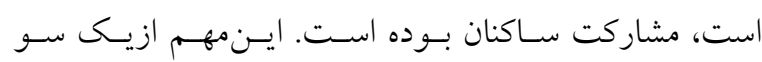

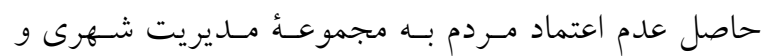

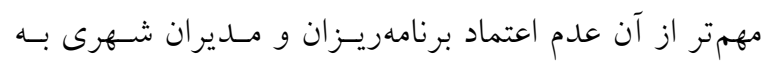

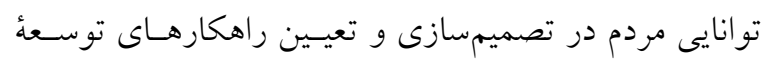

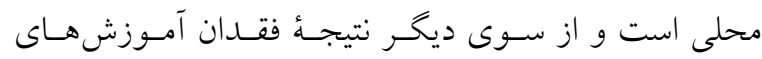

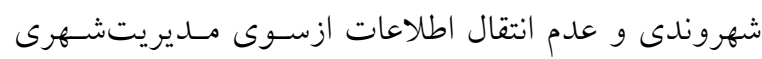
بهمردم، نبود زيرساختهاى آمـوزش اجتمـاعى بـهــاكنان،

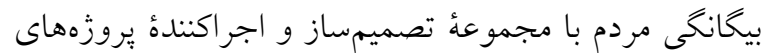
توسـعة محسلات شـهرى و دخيـلن نبـودن مـردمدر سـاختار تصميم گيرى براى توسعلة محلـه اسـت. يكسى از مهـم تـرين

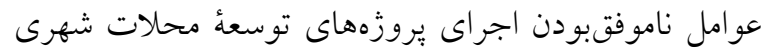
درايران عدم توجهبه نقش ساكنان ايسن محسـدوده از شهرها

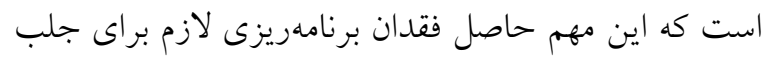

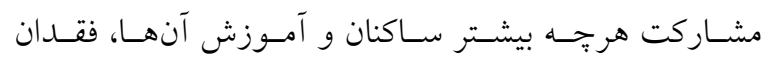

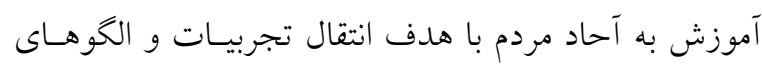

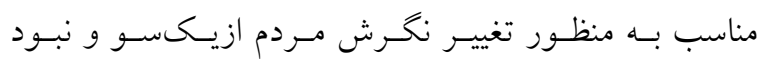

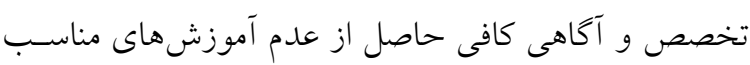

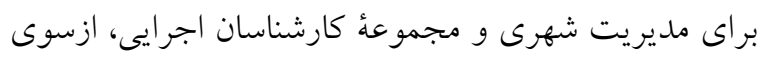

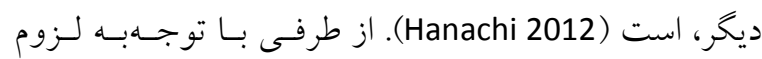

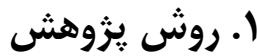
روش تحقيق در يزوهش حاضـر، بـهلحـاظ هــف بنيـادى و

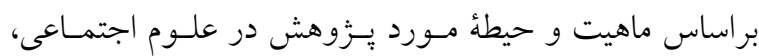

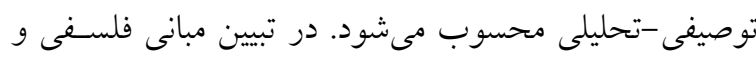

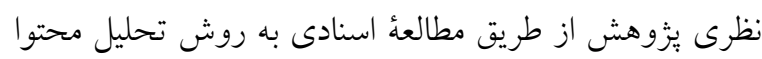

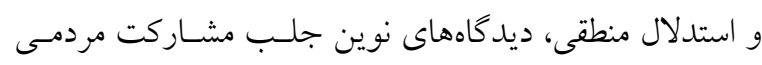

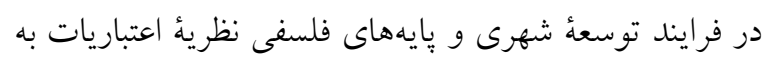

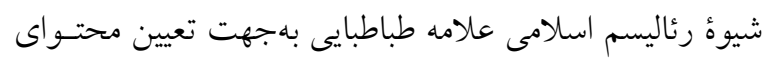

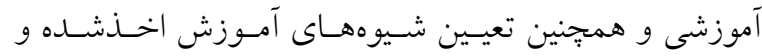


واكاوى خاستخاه فلسفى آموزش به اجتماع در فرايند مشاركتيذيرى شهروندان از منظر روش رئاليسم اسلامى

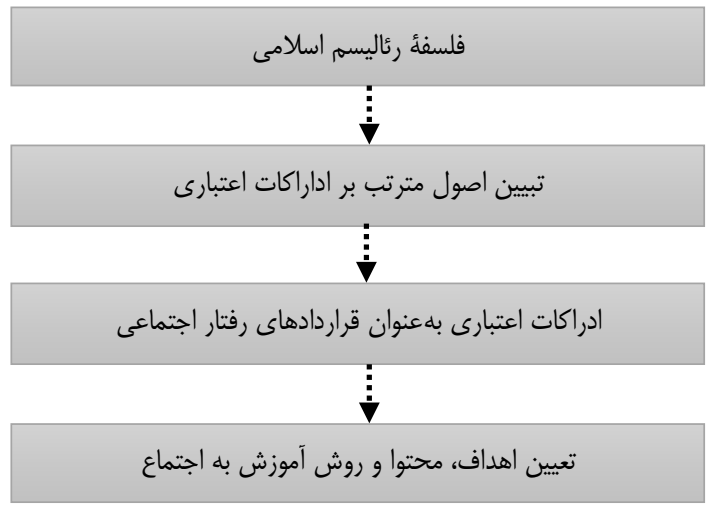

تصوير I : رابطؤ بين ادراكات اعتبارى و آموزش به اجتماع

Fig. 1: Relation between credit perceptions and education

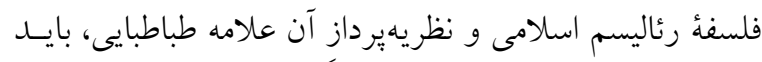

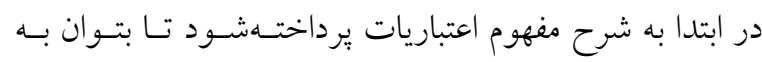

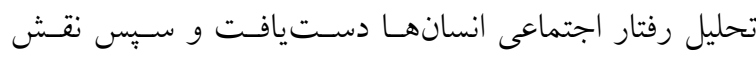

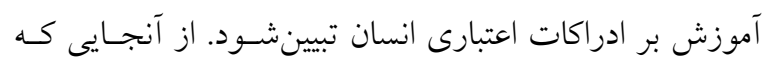

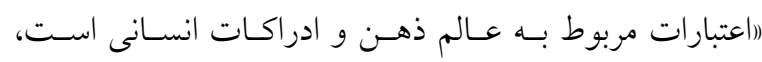

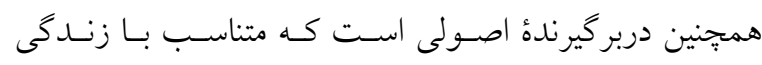

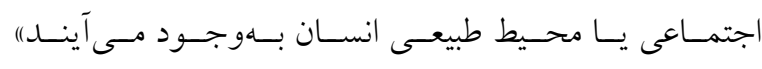

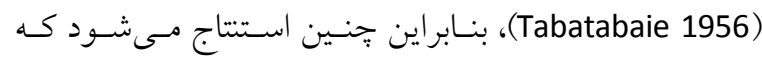

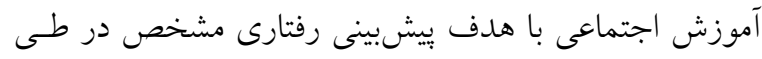
فرايندى مشخص، مىتواند به لحاظ تعيين اهــاف، محتـوا و

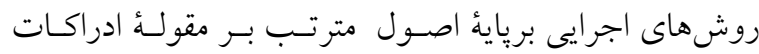

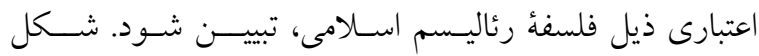

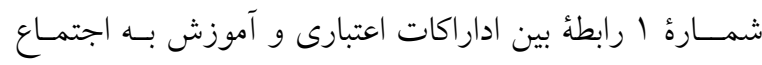

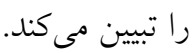

\section{معرفتشناسى اعتباريات از ديدكَاه علامه طباطبايى}

نظرية اعتباريات علامـه طباطبـايى، در مقالـهُ ششـم از كتـاب

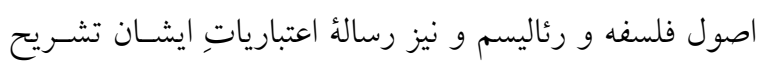

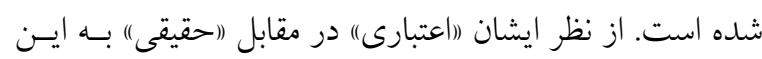

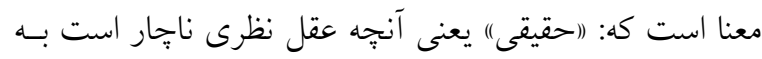

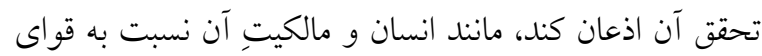

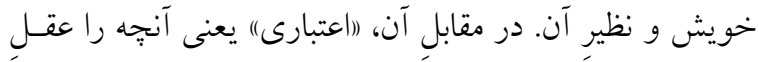
عملى براى نيازمندى انسان در معيشـتِِ اجتمـاعى مسىسـازد.
اسلامى شامل: برورش نيروى تفكر، برورش حس مســوليت

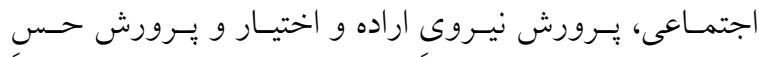

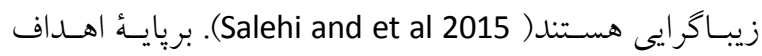

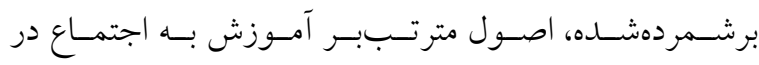

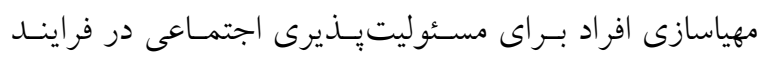

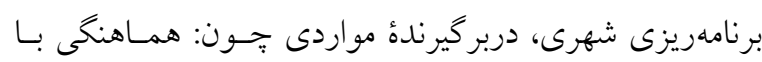

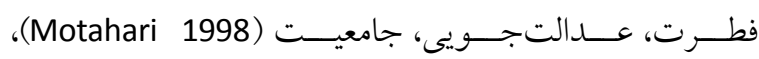

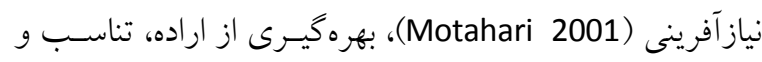

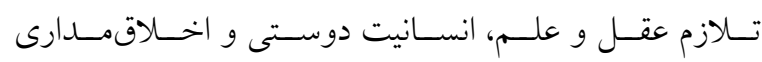
(Motahari 1995)

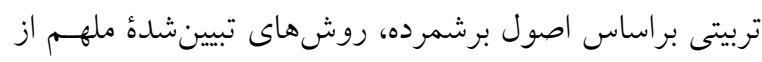

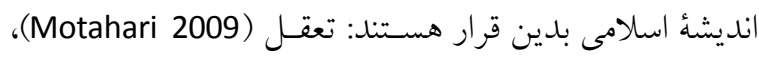

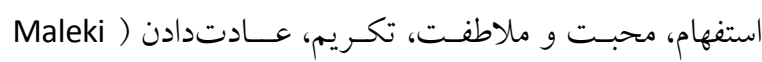
2005) و نقش الخويى (Salehi and et al 2015).

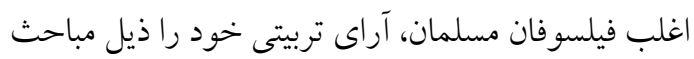

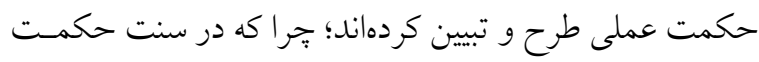

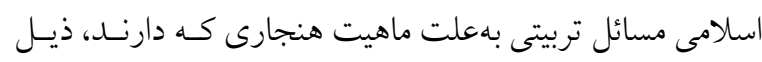
(احكمت عملى كه مهمترين ويزگى آن نيز ماهيـت هنجـارى و بايستى اشت) (Motahari 2009) تعريف شدهاند.

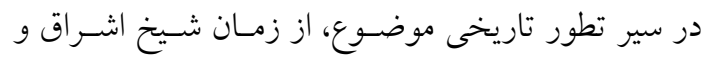

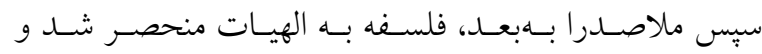

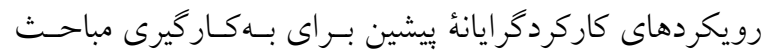

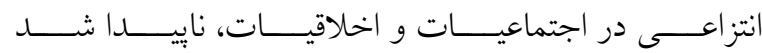
(Khosropanah 2005). به نظر مىرسد دليـل اينكـه درحـال

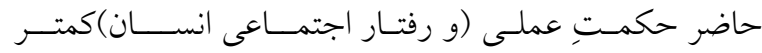

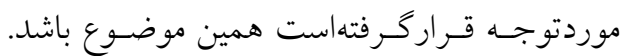

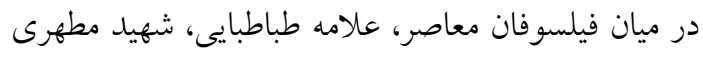

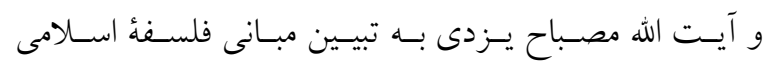

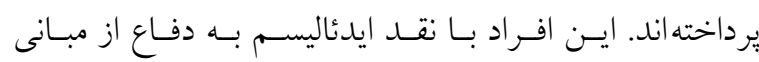
رئاليستى فلسفة اسلامى مبادرت ورزيدهاند.

\section{نقش آموزش در رفتار اجتماعى از ديدكاه فلسفهُ

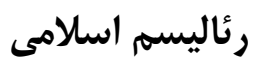

به منظور تبيين نقش آموزش در روابط اجتماعى از ديدكاه 
از عناصر مهم در كشف اعتباريات است. جֶون اعتبارات، ساختار روابط اجتماعى و ساختار افعـال

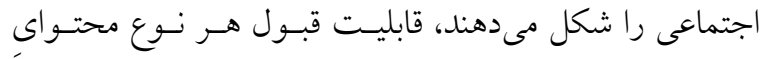

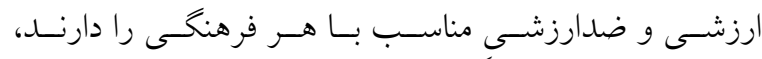
ساختارى كاملاً ابزارى دارند و در هر رابطةُ اجتماعى حضسور

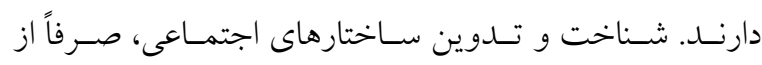
روابط اجتماعى بهدست مى آيند و به طور كلـى در هـر عمـل يبيجيده يا ساده اجتماعى، همهُ اعتبارات توسط انسـان سـاخته مىشود. براسـاس دسـتهبنــى افعـال انسـانى، دو دسـته مفــاهيم اعتبارى وجود دارند: افعال قبـلاز اجتمـاع (افعـال فـردى) و ولى افعال بعد از اجتمـاع (فعـل اجتمـاعى) (Tabatabaie 2007).

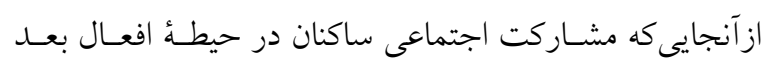
اجتماع دستهبندى مسىشـود، اصـول متــرتبـــر اعتبــاريات بعدالاجتــماع بر آن حكمفرما است. اين اصـول، شـامل اصـل كلام-سخن و اصل تســاوى طرفين مىباشــن ( Tabatabaie 2008). بر پائه اين اصول با اندكى عامنكرى مسىتـوان جنـين

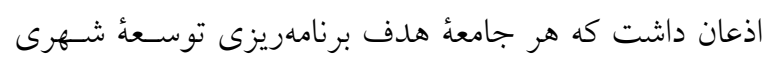

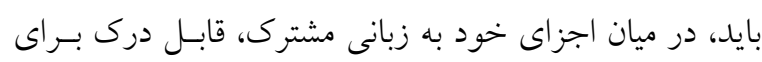

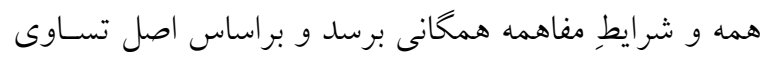
طرفين، براى شيوه مشـاركت اجتماعى كه بريائه سود سـاكنان

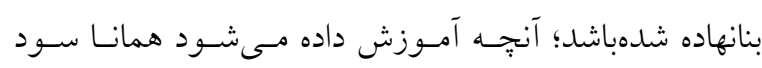

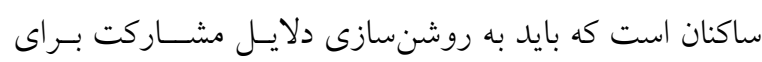
منتفع شدن از سودِ حاصل از آن بيردازد.

\section{نقش آموزش بر ادراكات اعتبارى}

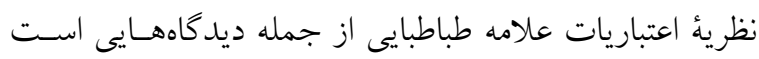
كه مى تواند نقش تعيين كننـدهاى در شـناخت و تحليـل رفتـار اجتماعى انسان داشتهباشد. مراد از اعتبار در نظريئ اعتباريـات، امورى است كه عقل عملى براى نيازمندى انسان در معيشـت اجتمـاعى مسىسـازد (Tabatabaie 1956). بـهـ زعــم علامـهـ طباطبايى، اراده، اولين اعتبار از اعتباريات محسوب مىشـود و

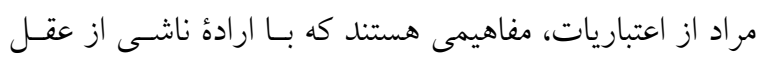
عملى ايجاد مىشوند. در باب تبيين نقش آموزش بر ادراكات

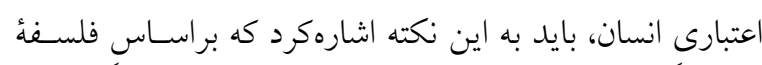

مانند عناوين رياست و مالكيت و زوجيت و نظاير ايـنهـا در سطح زندگى اجتماعى، كه عقل نظرى بـراى اينخونـه معـانى هيج گونه تحقق و اثرى نمى بيند، ولى عقلٍ عملى در مسـتواى

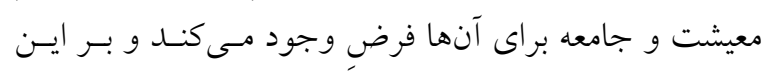

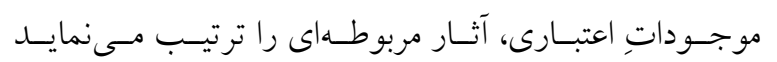

.(Tabatabaie 2008)

در يزوهش حاضر نيز منشأ شناخت حيطههاى تأثيركـار

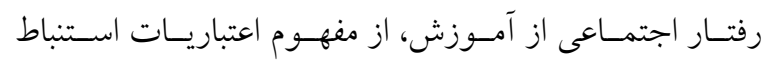

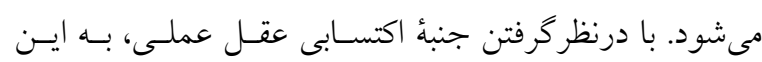

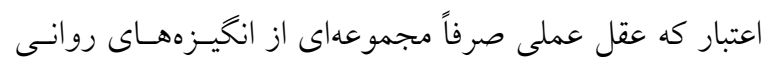

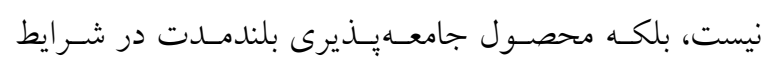
اجتماعى خاص و يا موقعيت معسين اسـت، مسىتـوان انتظـار

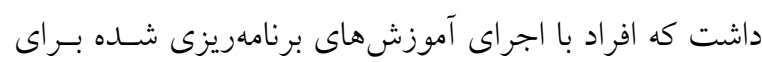

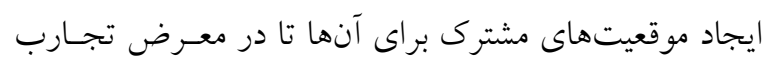
مشترك قرار بخيرنــا، رفتارهـاى اجتمـاعى مشـتركى را بــروز

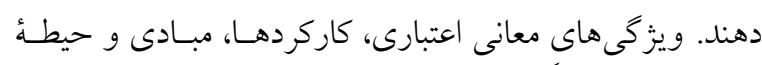

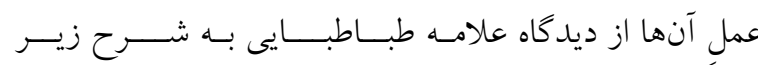

تبيـين شدهاند (Tabatabaie 2007 ; Tabatabaie 2008): (1) اعتبارات، ساختار مفهومسازى عقل عملى هستند.

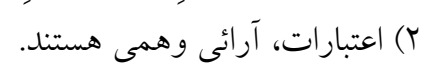

(r) اعتبارات در هر موجود داراى اراده، وجود دارد.

$$
\text { ع)|عتباريات معانى غيرحقيقى هستند. }
$$

0) اعتباريات براساس معانى حقيقى ساخته مىشوند.

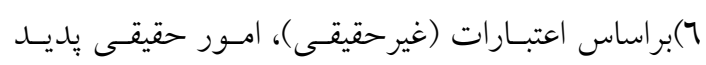

(V صدق اعتباريات بر جهان خارج، دائمى است. ^) اعتباريات، معانى برساخته عقل عملى هستند. 9) عقل عملى، معانى اعتبارى را در ظرف وهم مى سازد.

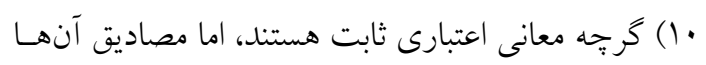
با تغيير نيازها، زمانها، فرهنخها و محسيط جغرافيـايى تغييـر (1) در اعتباريات برهان جريان ندارد. مى كنتل.

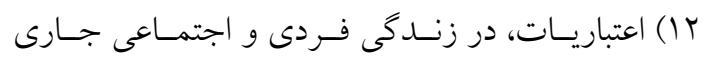
با (1) مشاهدهُ رفتار، زندكى و نحوهُ تعامل انسانها، يكى 
واكاوى خاستكاه فلسفى آموزش به اجتماع در فرايند مشاركتيذيرى شهروندان از منظر روش رئاليسم اسلامى

\section{تعيين اهداف و ويزَى هاى آموزش به اجتماع

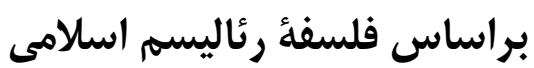

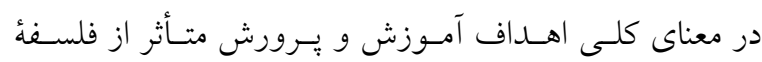

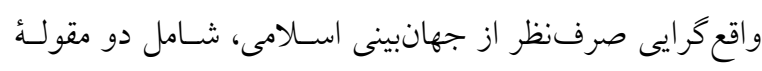

زير است (Gotek 2001)

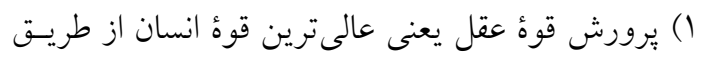

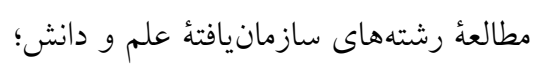

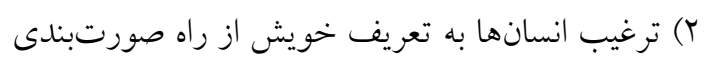

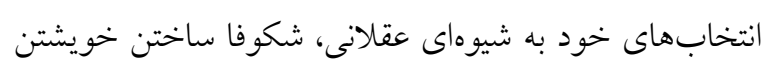

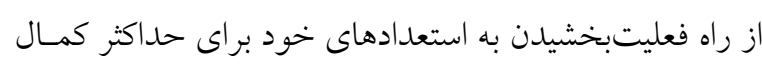

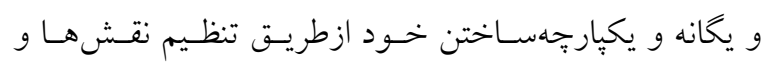

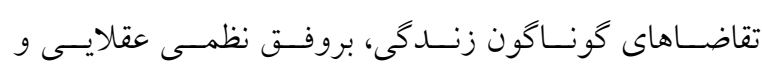

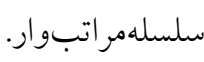

براساس مبانى هستىشناسى و انسانشناسى از نظر علامه

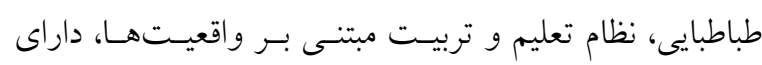

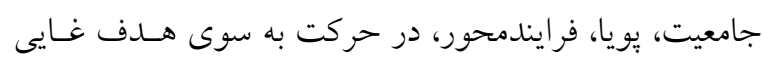

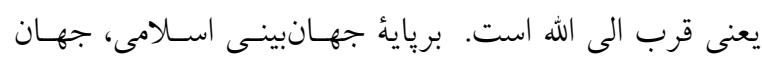

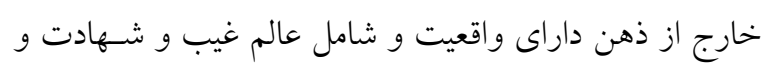

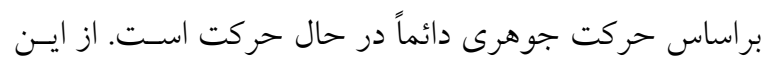

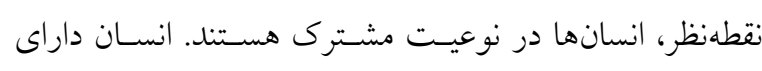

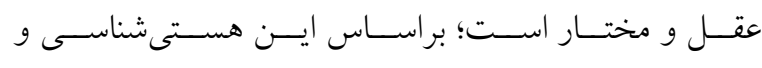

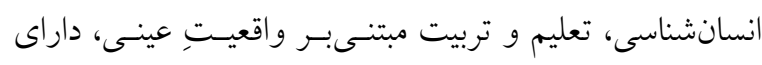

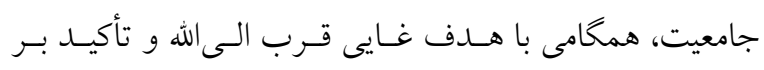

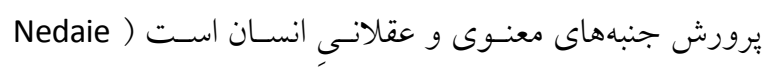

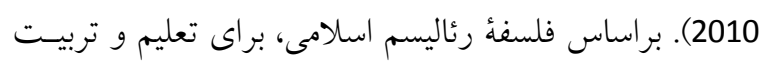

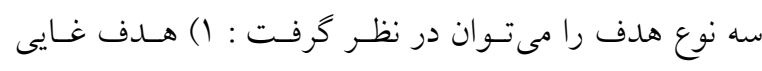

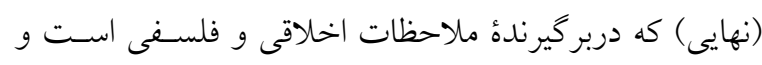

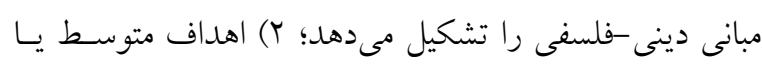

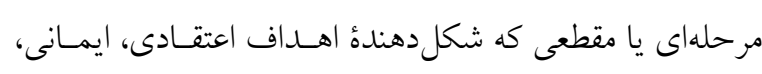

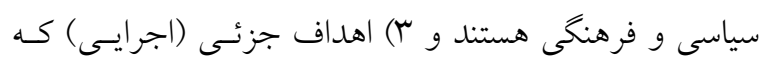

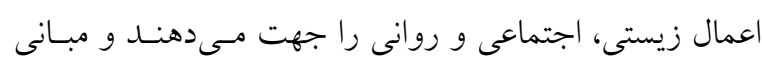

$$
\text { علمى را دربرمى گيرند (همان). }
$$

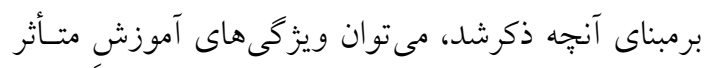

ازاين جهانبينى را، بدين شرح برشمرد (Mesbah 1981):

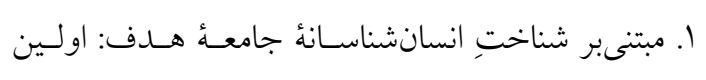

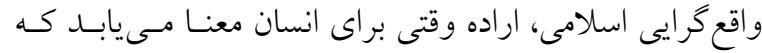

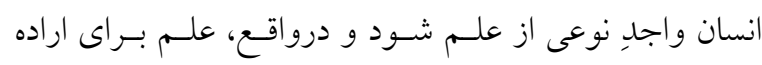

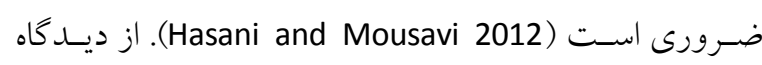

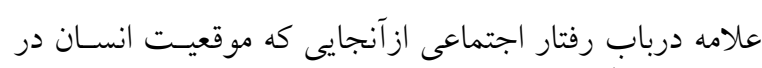

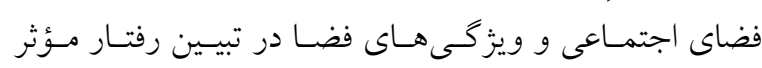

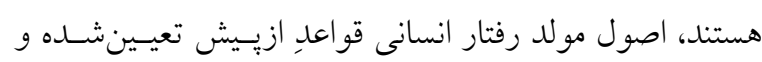

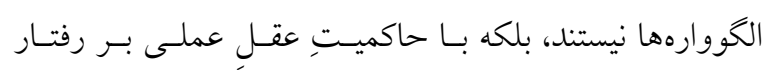

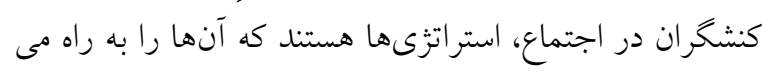

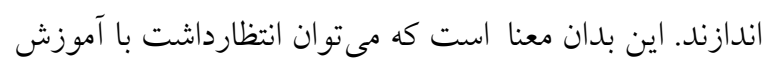

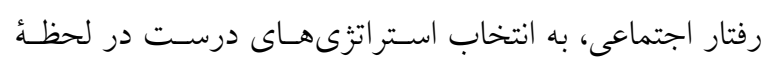

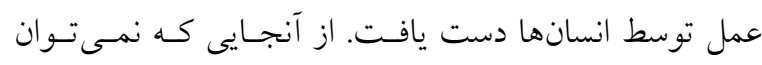

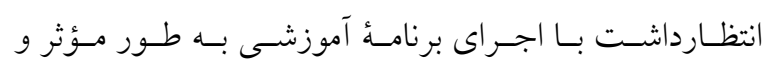

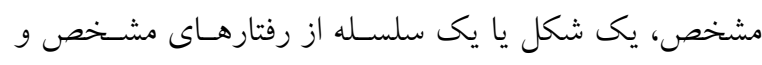

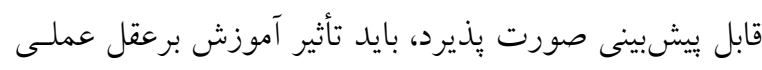

$$
\text { كنشخران سنجيده شود. }
$$

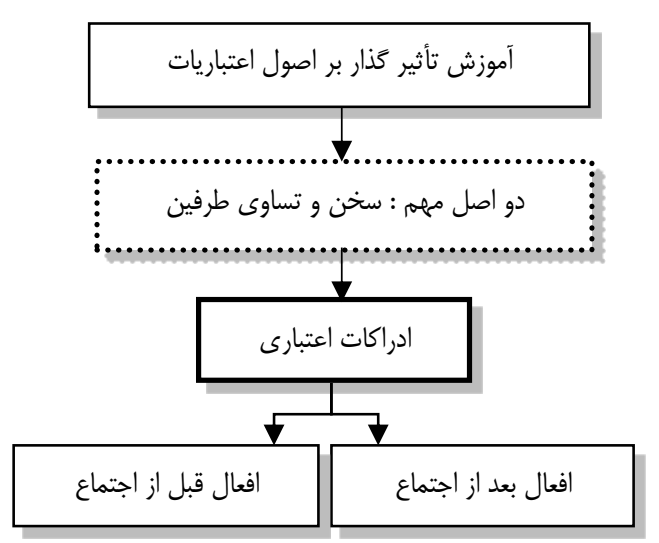

تصوير r : نقش آموزش بر ادراكات اعتبارى

Fig. 2: The effect of education on credit perceptions

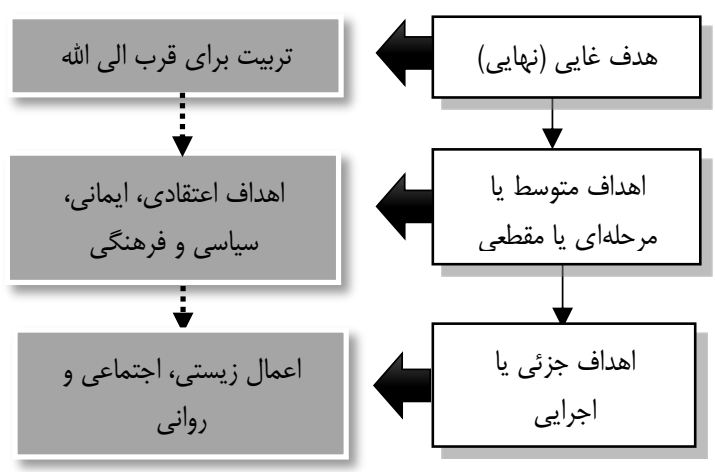

تصوير سّ: دسته بندى اهداف تعليم و تربيت براساس فلسفةُ رئاليسم اسلامى

Fig. 3: Classification of education goals based on the philosophy of Islamic realism 
متفاوت هستند و عواملى نظيــر سـن، سـواد، نـز اد و شـرايط

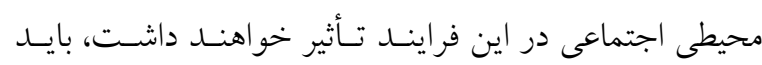

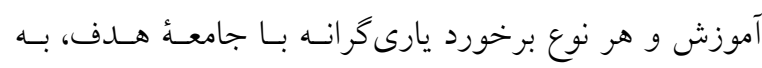

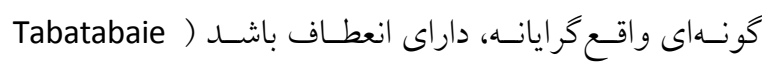

. 2007

^. برياية تعيين اولويتهاى محتواى آموزشى: باتوجسهبـه.

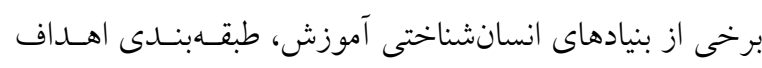

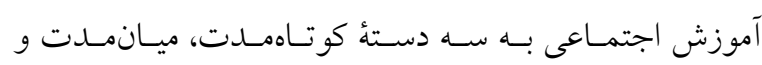

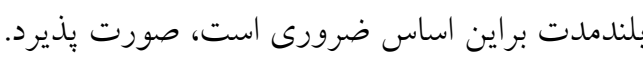

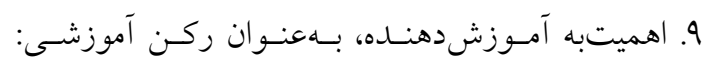

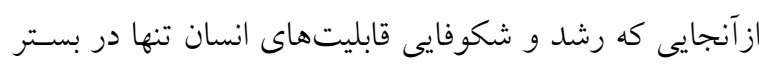

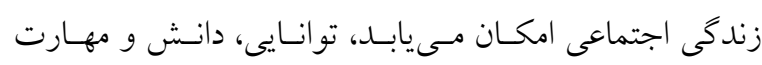

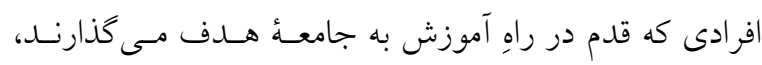

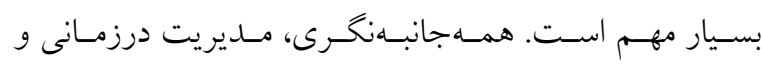

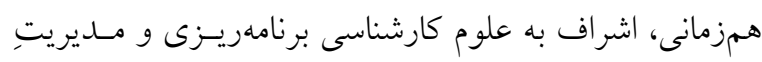

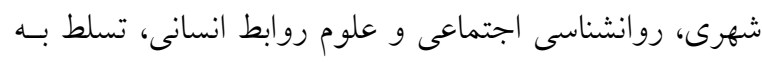

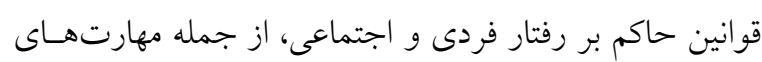
مورد نياز اين افراد هستند.

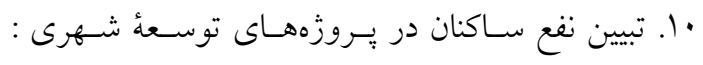

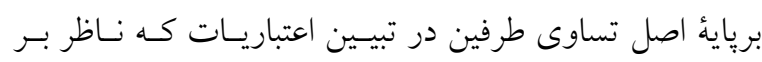

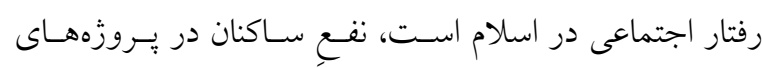

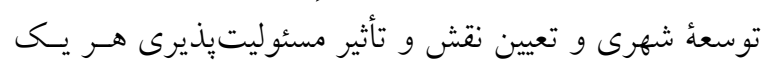

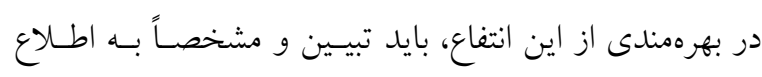

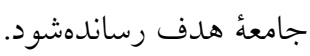

\section{واكاوى جايتًاه آموزش در نظريههاى

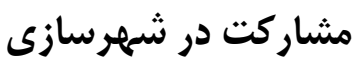

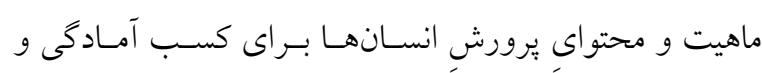

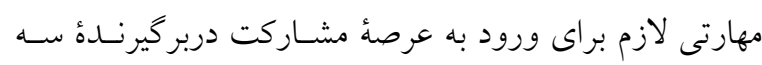

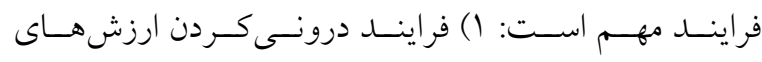

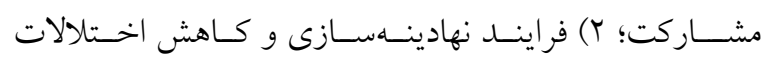

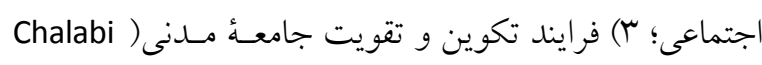

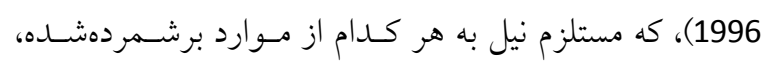

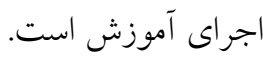

مرحله از اقدامات مرتبط بــا آمـوزش مقـولات اجتمـاعى بـهـ

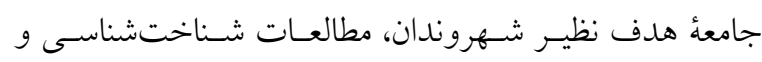
انسانشناسى خواهلدبود.

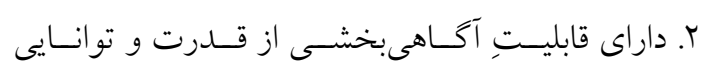

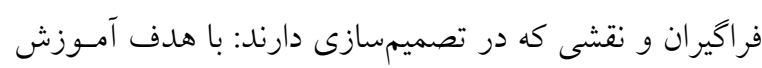

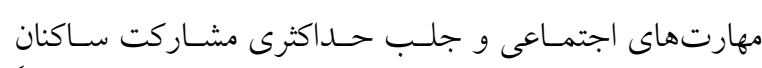

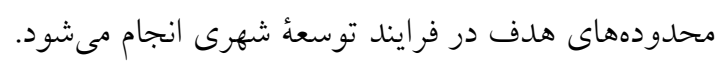

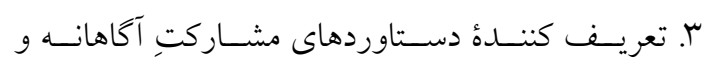

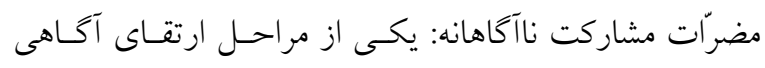

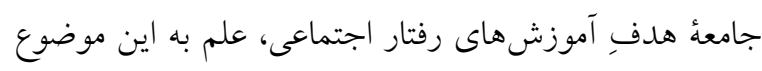

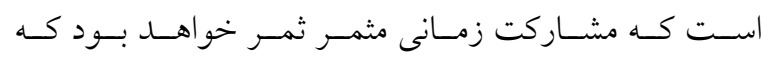

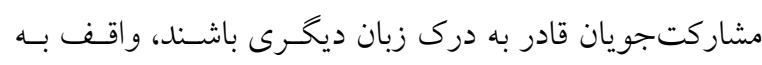

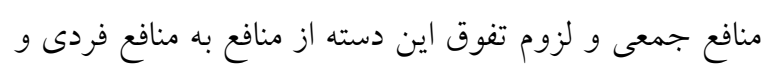
كاه منافع آنى باشند. ع. تبيين كندة حقوق شهروندان در مقابل تكـاليفشـان: در روابط اجتماعى، انسانى كه صاحب حق است، مكلّـف نيـز

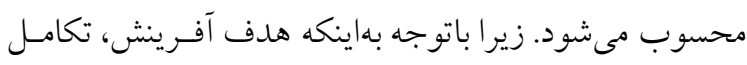

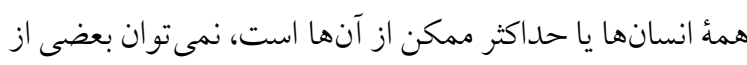

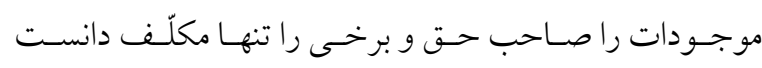
.(Nabavian 2011; Mesbah Yazdi 2003) 0. متكى بر تفويض نقشِ اجتماعى به سـاكنان: آمسوزشِ

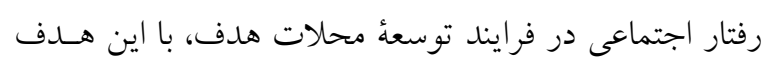

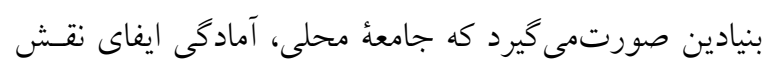

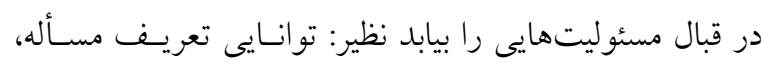

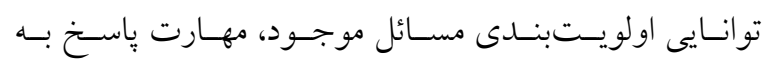
مشكلات و تقويت روحيئ مطالبه گرى.

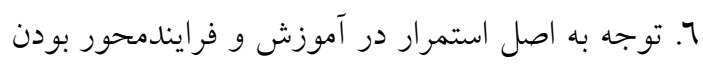

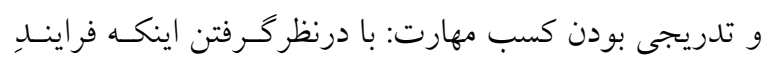

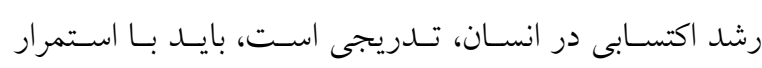

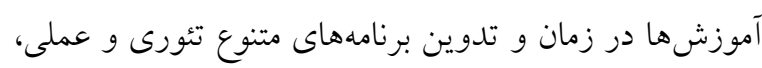
احتمال موفقيت را افزايش داد.

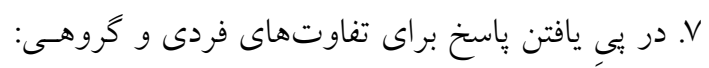

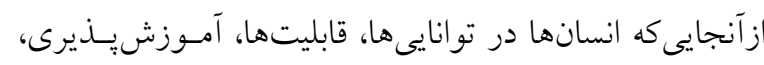

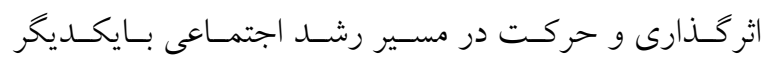


واكاوى خاستكاه فلسفى آموزش به اجتماع در فرايند مشاركتيذيرى شهروندان از منظر روش رئاليسم اسلامى

انجام مشــاركت بـــاى اجتنـاب از فرسـودن و خسـته شــن

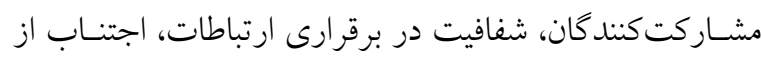
اتخاذ نتيجه كيرىهاى از ييش تعيينشده، محوريـت قـراردادن

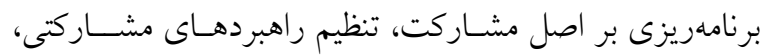

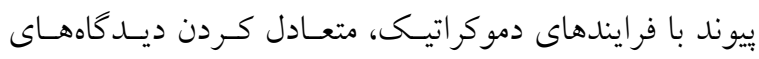
متضاد از طريق تصميم گيرى در مسائل عميق با نقـش آفرينـان

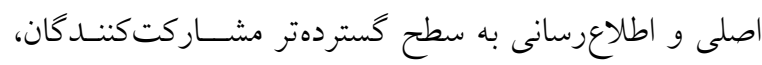

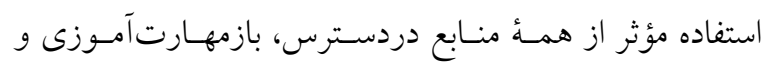

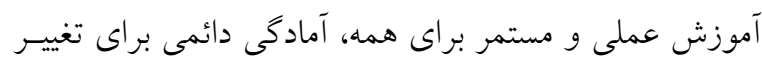

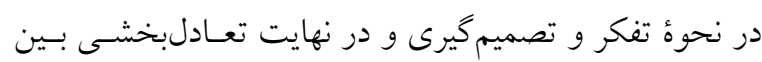

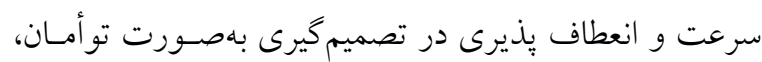

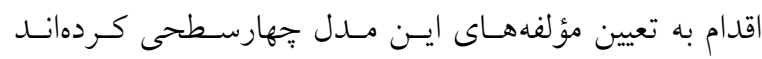

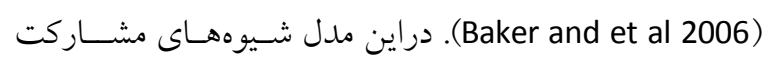

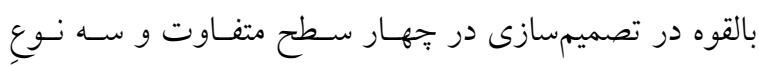
مشـاركت طبقـهبنـدى مسىشـوند كـه ايسن سـه نـوع شـامل:

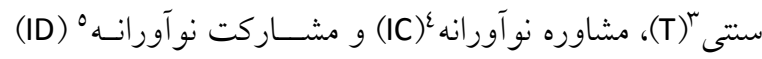

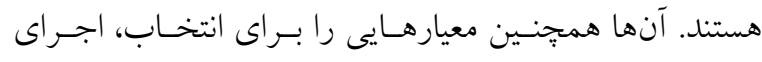

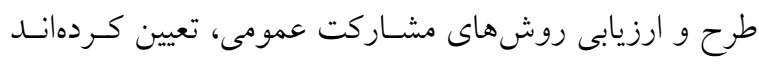

.(Petts and Leach 2000)

\section{ج) نظرئ انجمن بين المللى مشـاركت مردمى IAP2 :}

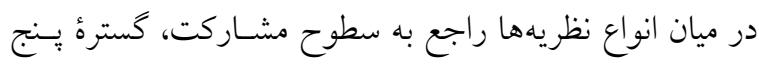

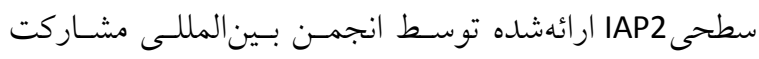

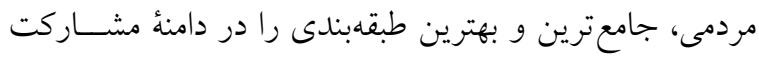

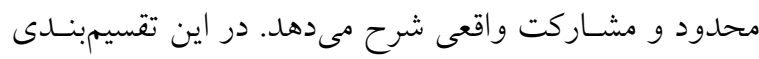

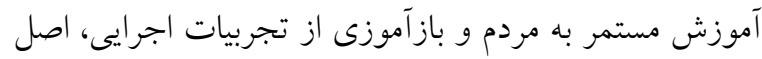
اساسى اين نظريه را تشكيل مى دهد.

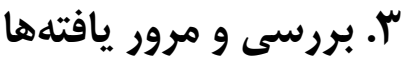
تبيين مفهوم آموزش اجتماعى در فلسفة رئاليسم اسلامى در مقايسه با نظريه أمنهاي

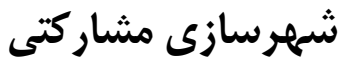

همانكونه كه نظريههاى برنامهريزى مشــاركتى عنـوان شـــه،

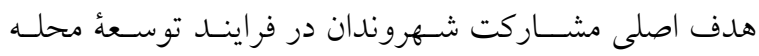

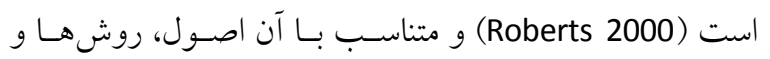

مجموعه نظرياتى كه تـاكنـون در خصـوص رابطـهُ بـين

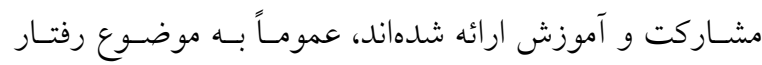
انسـان و مشـــاركت او در تحقـق اهـــاف در ســازمانهــا

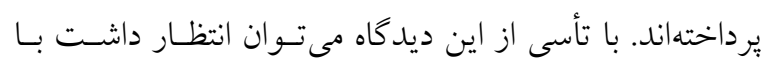

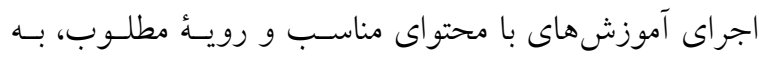

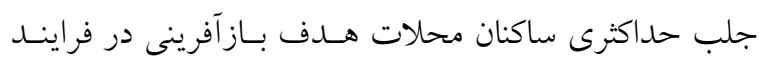

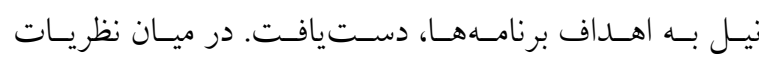

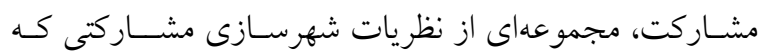

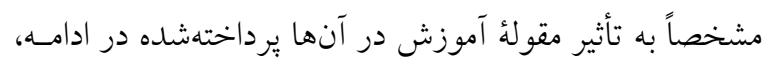

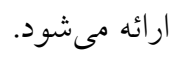

الف) نظرية اسكات ديويدسـون' : ديويدسـون در سـال

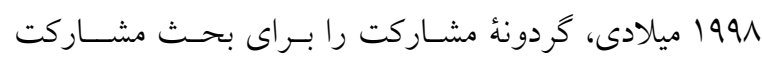

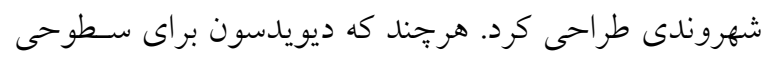

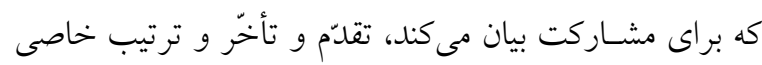

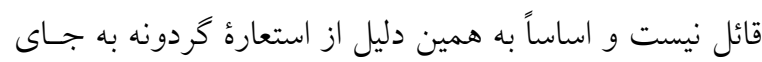

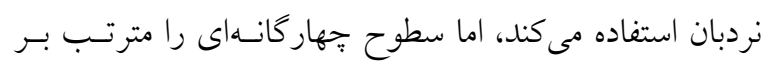

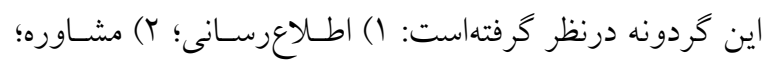

$$
\text { r) مشـاركت و ع) مقتدرسازى. }
$$

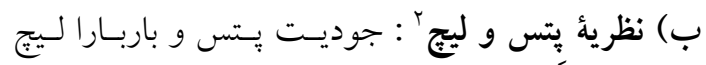

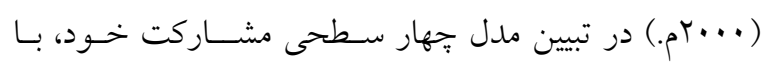

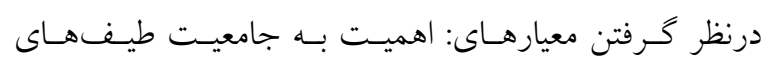

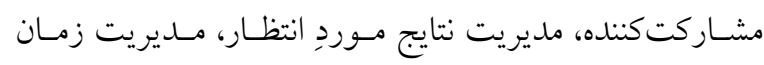

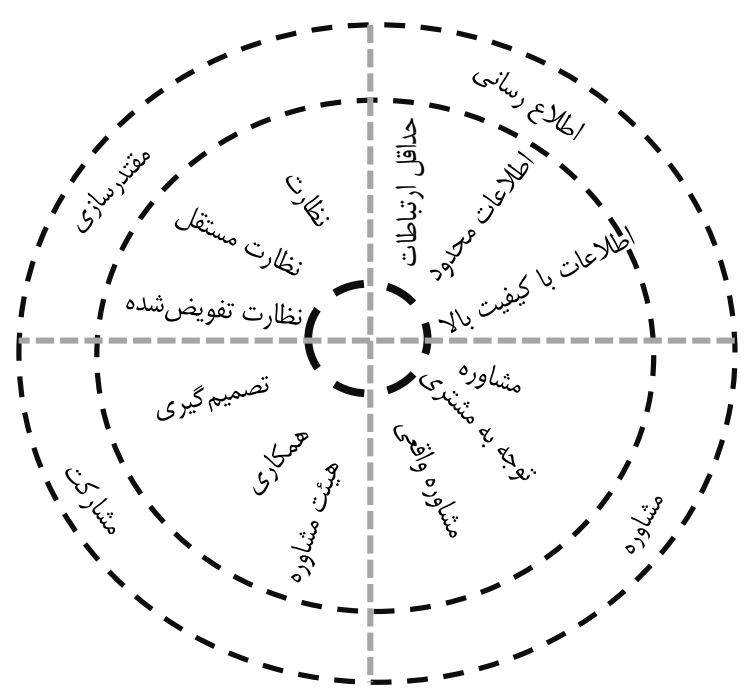

تصوير ع: مدل مشاركت ديويدسون(Davidson 1998) Fig. 4: Davidson participation model (Davidson 1998) 


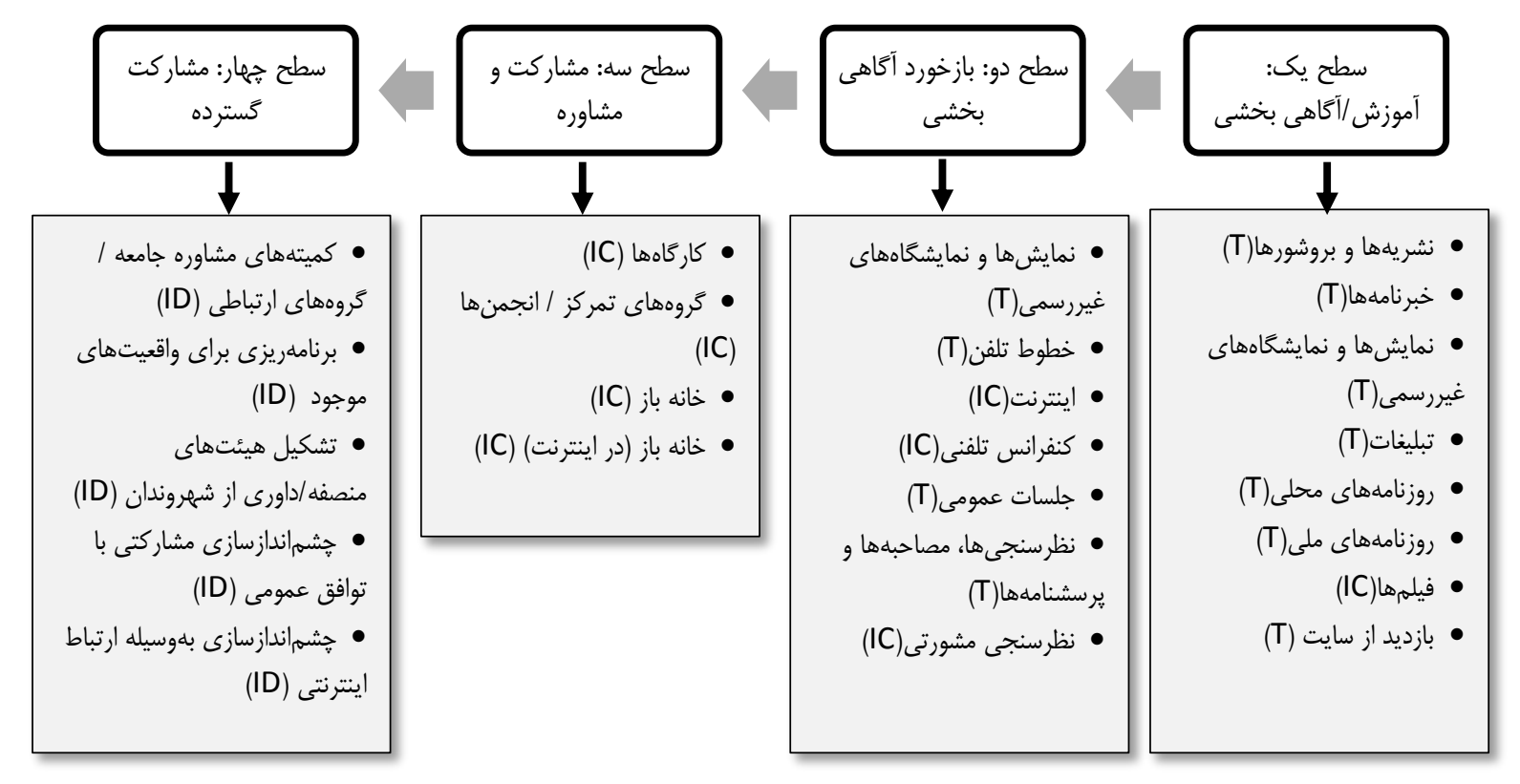

تصوير ه: مدل جهار سطحى مشـاركت ذينفعان يتس و ليج (Petts and Leach 2000)

Fig. 5: Four-level model of Petts and Leach stakeholder partnership (Petts and Leach 2000)

اسلامى مشاركت اجتماعى، در گرو آكاهى از نفـع حاصل از

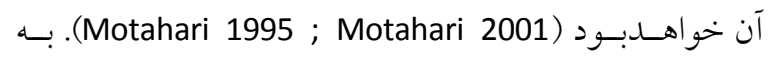
طوركلى علىرغم تفاوتهايى كـه در عنساوين بـهـاررفتـهـ در تبيين مبانى نظرى و فلسفى هر يكى از دو ديدگاه وجــود دارد، مىتوان مشابهتهايى در جهت كيرى كلى تبيين نقش آموزش

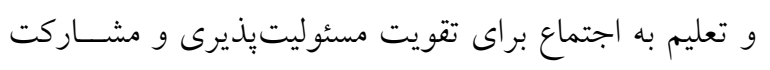

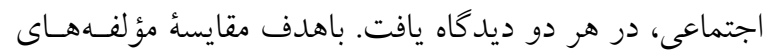

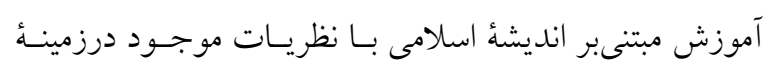

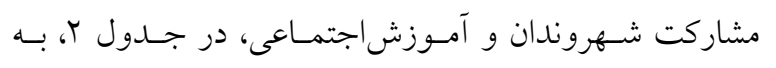
بررسـى موضـوع غرداخته شـدهاسـت.
محتــوا تــدوينشــدهاسـت، درايـن ديـــاه مشـــاركت حـق شهروندان تلقى مىشود (Abdi Daneshpour 2015). درمقابل، در انديشهُ اسلامى، مشخصاً به موضوع مشـاركت اشارهنشـده

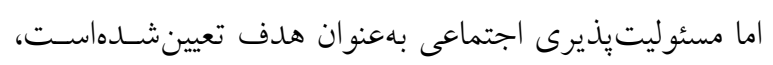

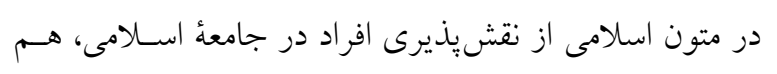
به بعنوان حق و هم تكليـف يـادشـدهاسـت ( Shariatmadari (1964; Tabatabaie 2008 همجينين در مقابل دو اصـل اساسى الـزام آَـاهى بــراى

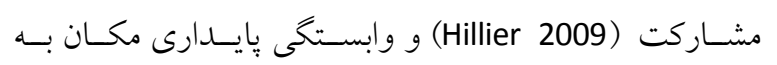

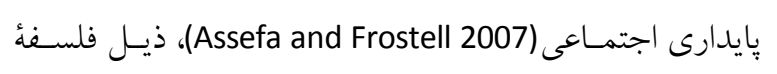

جدول (: كستره مشـاركت براساس Sharafi and Barakpour 2010) IAP2) Table 1: Participation scope based on IAP2 (Sharafi and Barakpour 2010)

\begin{tabular}{|c|c|c|c|c|c|}
\hline 1آكاهىرسانى 1. & مشورتج & درگير ساختن مردم^ & همكارى با مردم & توانمندسازى؟ & \\
\hline تـأمين اطلاعـات جـامع و & كرفتن بازخوردها & كار مستقيم با مردم در تمام طـول & شريك بودن بــا مـردم & دادن اختيــــــــار & \\
\hline عينى به منظور كمــ بــــ & از مردم در زمينه & فرايند به منظور دادن اطمينان بــه & در تمــــــامى ابعــــــاد & تصـميهم نهـايى & \\
\hline مـردم در فهــم مشـكلات، & تحليــــلــهـــــا، & مردم كه نخرانىها و علايق آنهـا & تصميهم گيـرى، شـامل & 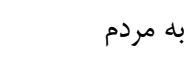 & اهــــــــاف \\
\hline كز زينههــا، فرصـتهـاو يـا & آلترناتيوهــا و يـــا & به شكلى مداوم در تمامى فرايند در & تكــــين آلترناتيوهــــــاو & & 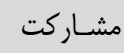 \\
\hline راهحلها & تصميمات & نظر كرفته خواهد شد & 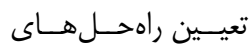 & & \\
\hline & & & منتخب & & \\
\hline
\end{tabular}


واكاوى خاستخاه فلسفى آموزش به اجتماع در فرايند مشاركتيذيرى شهروندان از منظر روش رئاليسم اسلامى

جدول r: مقايسُٔ مؤلفهاى آموزش اجتماعى در نظريههاى شهرسـازى مشـاركتى با انديشأ اسلامى

Table 2: Comparison of components of social education in participatory urban planning theories with Islamic thought

\begin{tabular}{|c|c|c|}
\hline مبانى نظرى انديشُٔ اسلامى در بابِ آموزش رفتار اجتماعى & نظريdهاى شهرسـازى مشـاركتى & مبانى \\
\hline 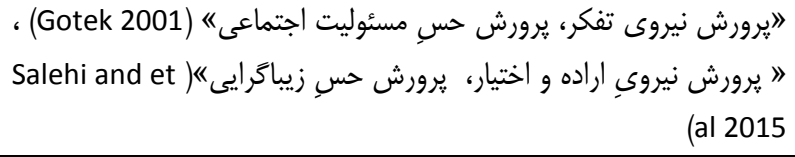 & مشـاركت شهروندان در توسعةُ محله (Roberts 2000) & 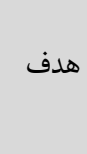 \\
\hline 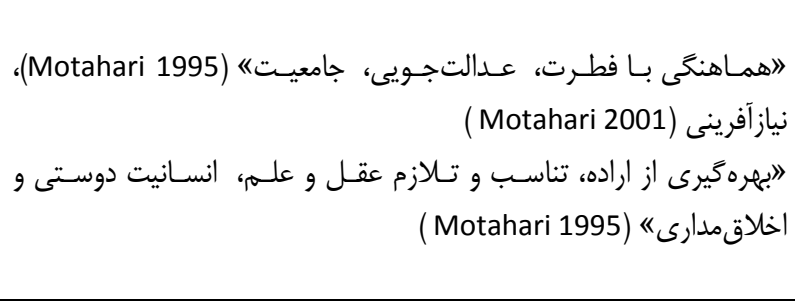 & 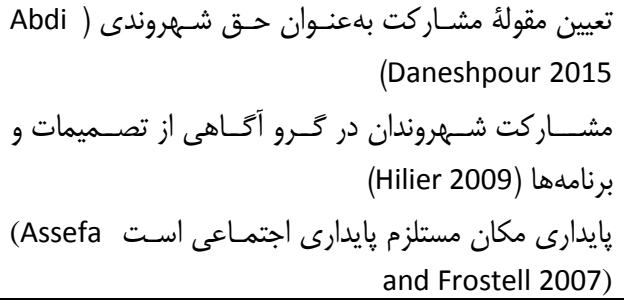 & 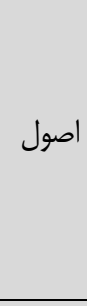 \\
\hline 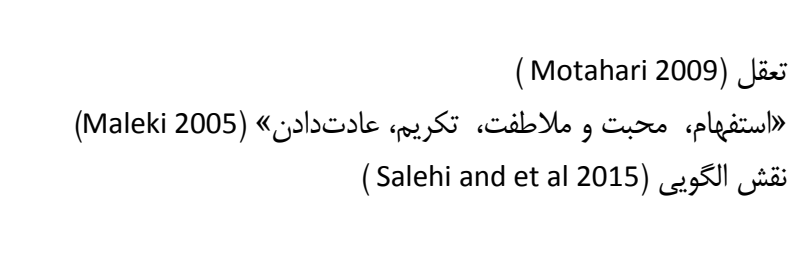 & 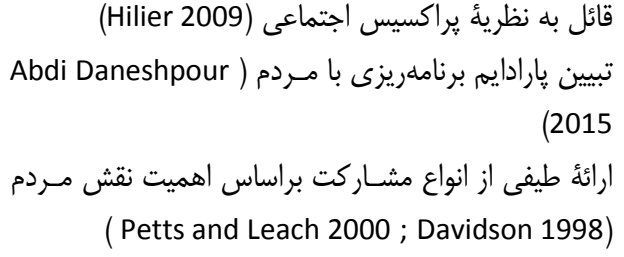 & 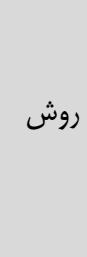 \\
\hline مسائل اخلاقى، مسئوليتيذيرى اجتماعى، حساس سازى نسبت بــه محـيط & آَاهىرسانى - توانمندسازى - ظرفيتسازى & توتوا \\
\hline
\end{tabular}

\section{نتيجهَيرى}

براى جامعه اصل است، و نـه آمـوزش بـه جامعسه. در ايسن جامعه ارزشها براساس انسانشناسى تبيين مىشوند.

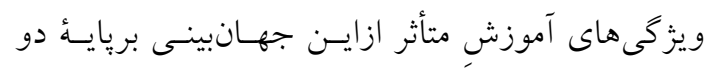

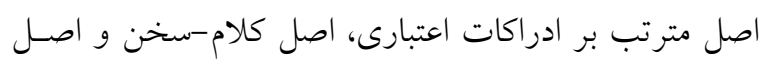
تساوى طرفين، مبتنىبر شناختِ انسانشناسانهُ جامعئ هدف؛

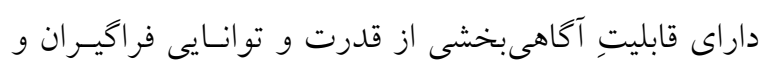

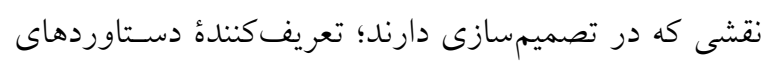

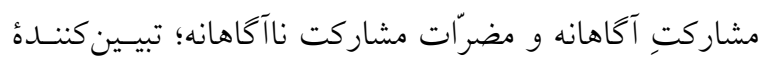

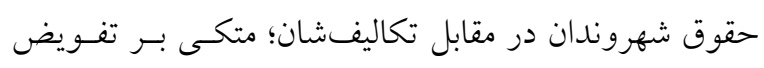

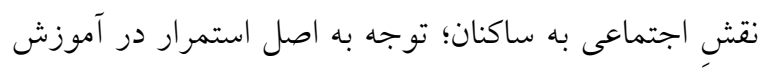

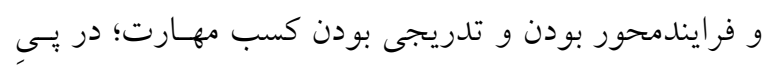

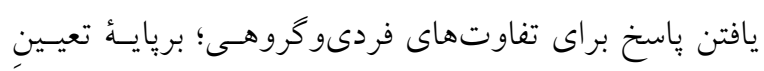

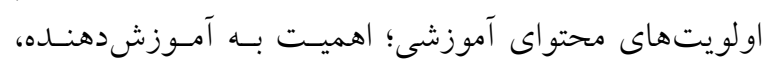

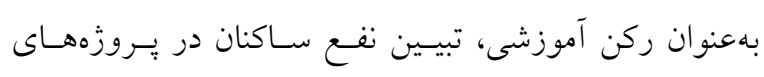

جمعبندى يافتها در بخش مبانى نظرى آموزش به اجتمـاع

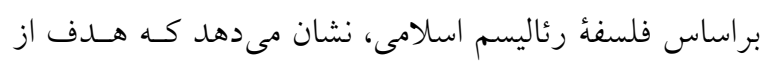

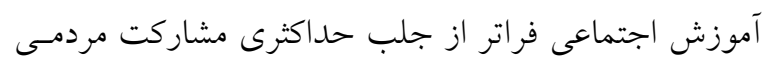

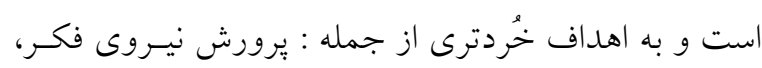
يرورش حس مسئوليت اجتمـاعى، يـرورش نيـروى اراده و

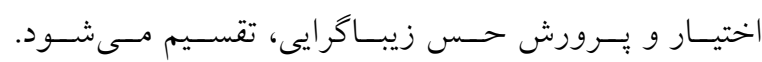
بدينترتيب هدف از اجراى آموزشهاى اجتماعى، يـرورش

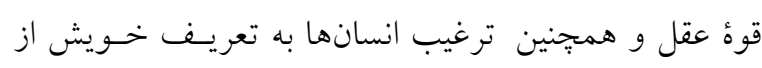

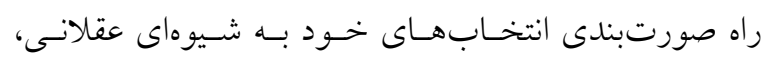

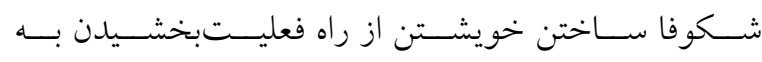

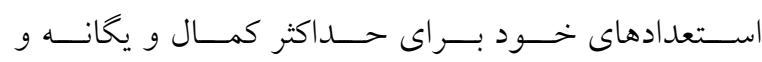
يكيار جهاخستن خود ازطريق تنظـيم نقـشهـا و تقاضـاهاى كوناگون زندگى، بروفق نظمى عقلايى و سلسـلهمراتـبـوار

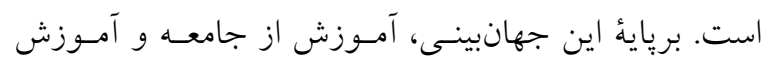


نشأت كرفته از هريك از دو جهانبينى برشمردهشـده اسـت. در مقابل انخاره كلى بيــروى از اكثريــت در تـدوين قـوانين حاكم بر اجتماع، ذيل انديشهُ اسلامى بيروى از حسق مطـرح

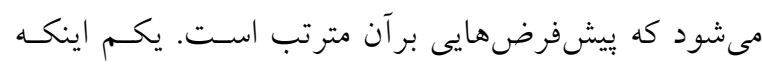

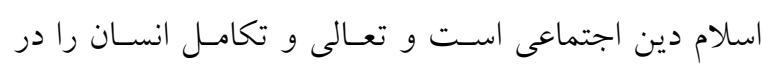

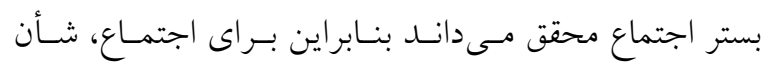
مستقل قائل است. دوم اينكه هدف هم سعادت دنيا استت و

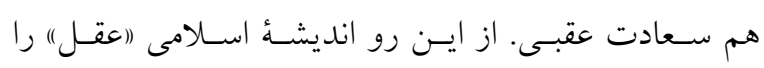
حاكمبر تنظيم قوانين رفتارى حاكم بر اجتماع مىدانـد. ايسن حق كه احصاء شدنى است، نيازمند تربيـت اسـت، بنـابراين آموزش و تعيليم و تعلّم در اجتماع نياز است.

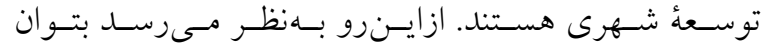

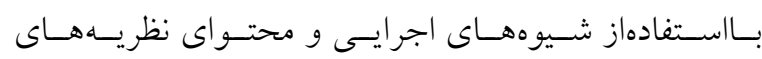

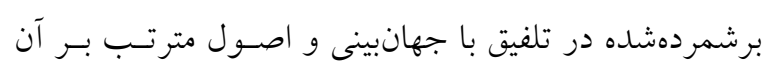

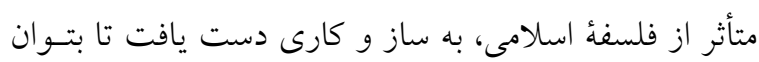
به جامعهُ اسلامى بويا و دخيـل در فراينــ تصـميم گيـرى و

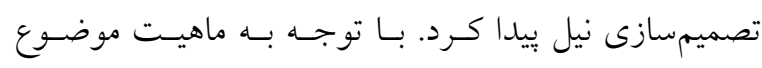
تحقيق، با مقايسٔ مفهوم اجتماعمحورى ذيل انديشهُ اسلامى لئ لئل

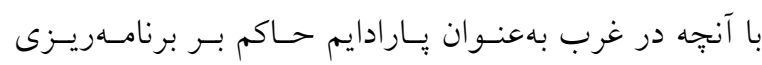

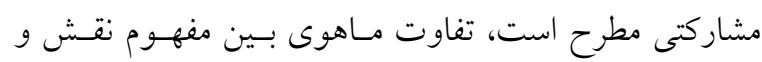

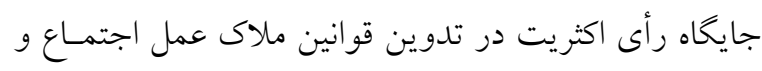

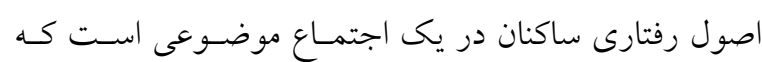

\section{Scott Davidson}

2. Judith Petts \& Barbara Leach

3. Traditional

4. Innovative Consultative

5. Innovative Deliberative

6. Empower

7. Collaborate

8. Involve

9. Consult

10. Inform

11. Archetypes

12. Ectypes

13. Diachronic

\section{يبىنوشت}

\section{فهرست منابع}

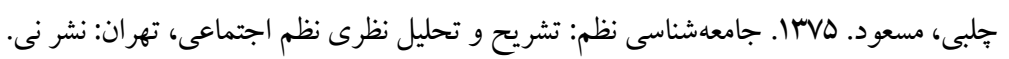

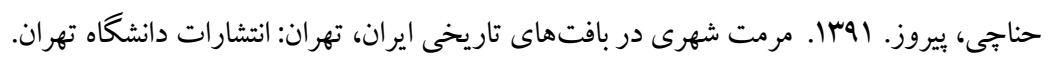

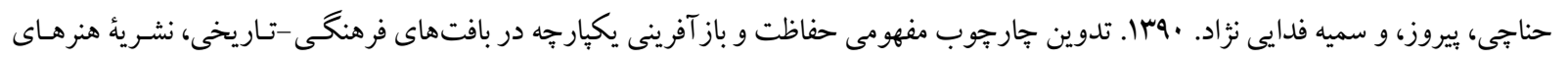

$$
\text { زيبا، شماره } 49 .
$$

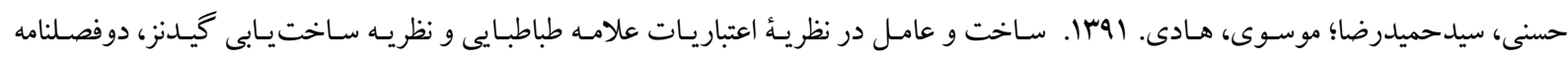
علمى بزوهشى نظريههاى اجتماعى متفكران مسلمان، سال دوم، شماره ب.

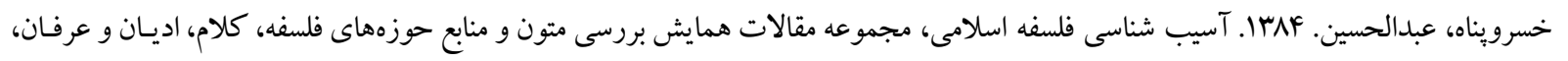

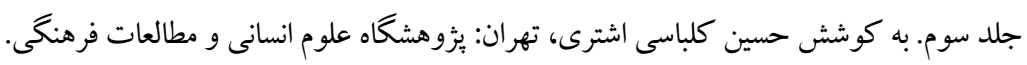

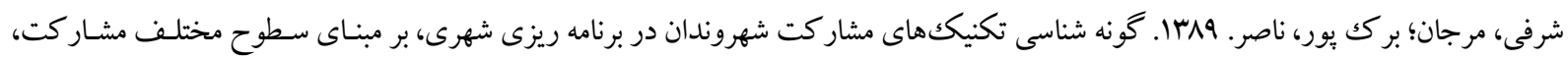
نامه معمارى و شهرسازى ، سال دوم شماره F.

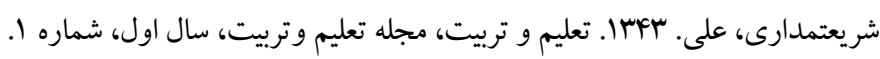

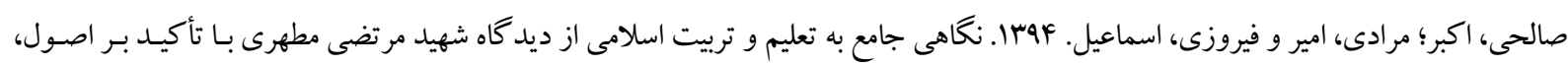

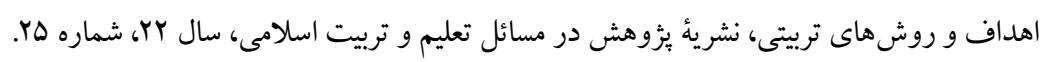


واكاوى خاستخاه فلسفى آموزش به اجتماع در فرايند مشاركتيذيرى شهروندان از منظر روش رئاليسم اسلامى

$$
\begin{aligned}
& \text { طباطبايى، محمدحسين. هسזا. اصول فلسفه و روش رئاليسم، ج ا، قم: دفتر انتشارات اسلامى. }
\end{aligned}
$$

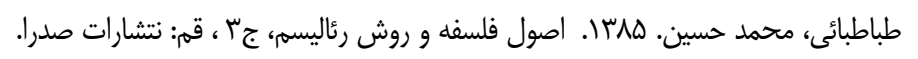

$$
\begin{aligned}
& \text { طباطبايى، محمدحسين. IrAV }
\end{aligned}
$$

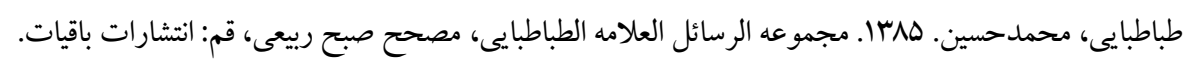

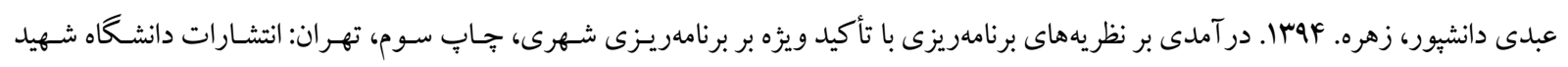

$$
\begin{aligned}
& \text { بكشتى. }
\end{aligned}
$$

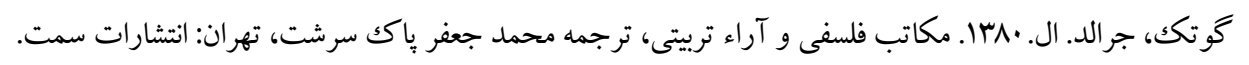

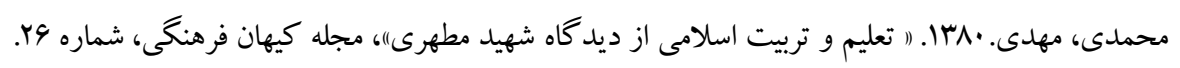

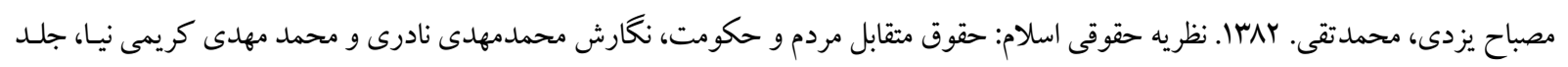

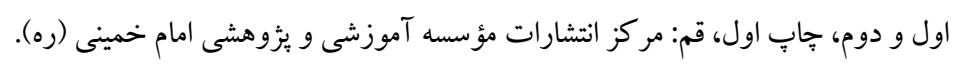

$$
\begin{aligned}
& \text { مطهرى، مرتضى. |IYI. تعليم و تربيت اسلامى، تهران: انتشارات صدرا. } \\
& \text { مطهرى، مرتضى. مط IMFF. سيرى در سيره نبوى، تهران: انتشارات صدرا. }
\end{aligned}
$$

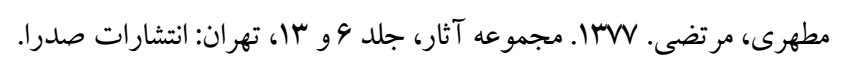

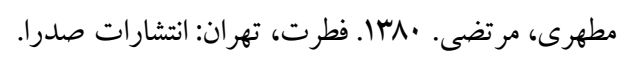

$$
\begin{aligned}
& \text { مطهرى، مرتضى. MMrا. كليات علوم اسلامى، كلام، عرفان، حكمت عملى، قم: انتشارات صدرا. }
\end{aligned}
$$

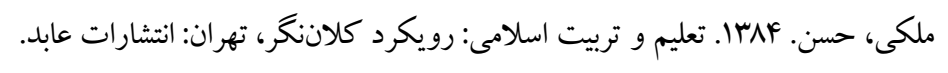

$$
\begin{aligned}
& \text { نبويان، سيدمحمود. MM M ا. فلسفه حق، قم: مر كز انتشارات مؤسسه آموزشى و بثزوهشى امام خمينى (ره). }
\end{aligned}
$$

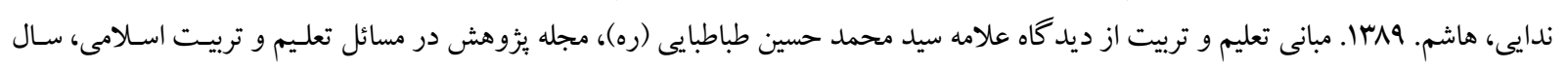

$$
\begin{aligned}
& \text {.11 } \\
& \text { هيلير، جين. MM ا. سايه هاى قدرت: حكايت دورانديشى در برنامهريزى كاربرى اراضى، ترجمه كمال يـولادى، تهـران: انتشـارات جامعـه مهندسـان } \\
& \text { مشاور ايران. }
\end{aligned}
$$

\section{منابع انخَليسى}

Abdi Daneshpour, Z. 2015. An introduction to planning theories with a special emphasis on urban planning. Third edition. Tehran: Shahid Beheshti University Press. [In Persian]

Assefa G. and Frostell B. .2007 Social Sustainability and Social Acceptance in \technology Assessment: A Case Study of Energy. Technologies in Society Journal. 29:63-78.

Chalabi, M. 1996. Sociology of order: theoretical description and analysis of social order. Tehran: Ney Press. [In Persian]

Gotek, J. L. 2001. Philosophical schools and educational ideas. Translated by M. Pakseresht. Tehran: SAMT. [In Persian]

Hanachi, P. and S. Fadaienejad. 2011. Develop a conceptual framework for integrated conservation and regeneration in cultural-historical contexts. Journal of fine arts. 3(46): 18-26.

Hanachi, P. 2012. Urban restoration in the historical contexts of Iran. Tehran: SAMT. [In Persian]

Hasani, H. and H. Mousavi. 2012. Construction and factor in Allameh Tabatabai's theory of credit and Giddens' theory of construction. Bi-Quarterly Journal of Social Theories of Muslim Thinkers. 2(2): 129-159.

Hilier, J. 2010. Shadows of Power: A Story of Foresight in Land Use Planning. Trnslated by K. Pouladi. Tehran: Publications of Iranian Society of Consulting Engineers.

Khosropanah, A. 2005. Pathology of Islamic philosophy. Proceedings of the conference on the study of texts and sources in the fields of philosophy, theology, religions and mysticism. Third volume. Collected by H. Kalbasi Ashtari. Tehran: Institute of Humanities and Cultural Studies.

Maleki, H. 2005. Islamic Education: A Macro Approach. Tehran: Abed Press. [In Persian]

Mesbah Yazdi. M. 2003. Islamic legal theory: the reciprocal rights of people and government. Collected by M. Naderi, and M. Kariminia. The $1^{\text {st }}$ and $2^{\text {nd }}$ volume. The $1^{\text {st }}$ edition. Qom: Imam Khomeini Educational and Research Institute Publishing Center. [In Persian]

Mohammadi, M. 2001. Islamic education from the perspective of Shahid Motahari. Journal of Cultural Universe. 26: 29-181. Motahari, M. 1992. Islamic Education and Training. Tehran: Sadra Press. [In Persian]

Motahari, M. 1995. Search in the prophetic way. Tehran: Sadra Press. [In Persian]

Motahari, M. 1998. The Collection. The $6^{\text {th }}$ and $13^{\text {th }}$ volume. Tehran: Sadra Press. [In Persian]

Motahari, M. 2001. The Nature. Tehran: Sadra Press. [In Persian] 
Motahari, M. 2009. Generalities of Islamic sciences, theology, mysticism, practical wisdom. Tehran: Sadra Press. [In Persian] Nabavian, M. 2010. Philosophy of truth. Qom: Imam Khomeini Educational and Research Institute Publishing Center. [In Persian]

Nedaie, H. 2011. Fundamentals of education from the perspective of Allameh Seyed Mohammad Hossein Tabatabai. Journal of Research in Islamic Education. 19(11): 29-42.

Petts, J. and Leach. B. 2000. Evaluation Methods for Public Participation: Literature Review. Bristol: Environment Agency.

Roberts, P. 2000. The evolution, definition and purpose of urban regeneration, A handbook, British Urban Regeneration Association. London: SAGE Publications.

Salehi, A. A. Moradi, and E. Firouzi. 2015. A comprehensive look at Islamic education from the perspective of Martyr Morteza Motahhari with emphasis on the principles, goals and methods of education. Journal of Research in Islamic Education. 22(25): 9-37.

Sharafi, M. and N. Barakpour. 2010. Typology of citizen participation techniques in urban planning, based on different levels of participation. Journal of Letter of Architecture and Urbanism. 2(4): 77-101.

Shariatmadari, A. 1964. Education and training. Journal of Education and training. 1(1): 1-15.

Tabatabai, M.H. 1956. Principles of Philosophy and the Method of Realism. Qom: Islamic Publications Office, Shahid Motahari Scientific and Cultural Foundation. V I \& II. [In Persian]

Tabatabai, M.H. 2006. Principles of Philosophy and the Method of Realism. Qom: Islamic Publications Office, Shahid Motahari Scientific and Cultural Foundation. V III. [In Persian]

Tabatabai, M.H. 2007. Collection of Al-Tabala Tabatabai Al-Rasa'il. Corrected by S. Rabiei. Qom: Baqiat Press. [In Persian]

Tabatabai, M.H. 2008. Social relations in Islam. Qom: Bostan Ketab. [In Persian] 